\title{
Freshwater biodiversity in human-dominated landscapes: introduction
}

\author{
Nisikawa Usio · Junjiro N. Negishi
}

Published online: 23 July 2014

(C) The Japanese Society of Limnology 2014

Worldwide, humans have converted natural wetlands into agricultural areas because of increasing demands for food. Rice paddy fields, farm ponds, fish ponds and irrigation and drainage ditches are typical landscape sectors in rural areas of Monsoon Asia and some parts of Europe and the Americas. Such habitats provide surrogate habitats for a range of aquatic wildlife that once inhabited natural wetlands (Elphick 2000; Lawler 2001).

Traditionally, scientists and policy makers have largely focused on designating relatively pristine areas as protected areas for biodiversity conservation. Although zoning or land sparing may be effective especially where large areas of natural habitats remain, in recent decades equal attention has been given to land sharing, in which biodiversity conservation and human use of natural resources are simultaneously promoted in the same area (Fischer et al. 2008). Both land sharing and land sparing have complementary roles in maintaining biodiversity and ecosystem services.

The concept of land sharing is not new, because all over the world people in rural areas have maintained and utilized natural resources for centuries. Specifically, humandominated landscapes in rural areas, also known as Satoyama, are characterized by a long history of human intervention with farmland, farm ponds, streams/ditches, grassland and secondary forests around villages (Katoh

\footnotetext{
N. Usio $(\bowtie)$

Institute of Nature and Environmental Technology, Kanazawa

University, Kakuma-mati, Kanazawa 920-1192, Japan

e-mail: usio@se.kanazawa-u.ac.jp

J. N. Negishi

Faculty of Environmental Earth Science, Hokkaido University, N10W5, Sapporo, Hokkaido 060-0810, Japan

e-mail: negishi@ees.hokudai.ac.jp
}

et al. 2009). Many organisms in Satoyama exhibit life history adaptations to moderate anthropogenic disturbances (e.g., Mukai et al. 2005). Therefore, traditional farming and forestry activities are keys to maintaining the biodiversity of Satoyama. However, biodiversity in Satoyama is threatened mainly by agricultural intensification and abandonment. Typical drivers of loss of Satoyama biodiversity include the use of strong agrochemicals, non-point pollution from farmland, land consolidation, invasion by nonnative species and farmland or forest abandonment as a result of depopulation and aging in rural communities (Natuhara 2013).

This special feature introduces biodiversity patterns in rice paddy fields, fish ponds and drainages, which have important biodiversity conservation functions beyond their roles of producing food or irrigation water. We begin with recovery patterns of macroinvertebrate diversity in Japanese paddy fields inundated by the tsunami from the Tohoku Earthquake in 2011 (Mukai et al. 2014). The next article by Wezel et al. (2014) introduces $\alpha$ - (single pond), $\beta$ - (between ponds) and $\gamma$ - (regional pond network) biodiversity patterns in nutrient-rich fish ponds in France. The subsequent article by Verdonschot and Verdonschot (2014) shows how aquatic macroinvertebrate diversity is influenced by shading effects of free-floating macrophytes in Dutch agricultural drainages. Finally, Negishi et al. (2014) model the distributions of imperiled bivalves in relation to landscape structure and fish diversity in Japanese agricultural ditches.

This special feature was written to provide case studies of freshwater biodiversity in Satoyama in Japan and their European counterparts, which have largely been ignored to date. The research papers published here cover various aspects of freshwater biodiversity, from biodiversity patterns to threats through recovery in three different 
countries, but do not provide a thorough account of the topic. We hope that this collection of work will stimulate further research in the field, especially where degradation of Satoyama habitats is of major concern.

We thank the editorial board members of Limnology for providing us the opportunity to publish this special feature, the authors for submitting their manuscripts and anonymous reviewers for reviewing the manuscripts.

\section{References}

Elphick CS (2000) Functional equivalency between rice fields and seminatural wetland habitats. Cons Biol 14:181-191

Fischer J, Brosi B, Daily GC, Ehrlich PR, Goldman R, Goldstein J, Lindenmayer DB, Manning AD, Mooney HA, Pejchar L, Ranganathan J, Tallis H (2008) Should agricultural policies encourage land sparing or wildlife-friendly farming? Front Ecol Environ 6:382-387

Katoh K, Sakai S, Takahashi T (2009) Factors maintaining species diversity in satoyama, a traditional agricultural landscape of Japan. Biol Conserv 142:1930-1936
Lawler SP (2001) Rice fields as temporary wetlands: a review. Israel J Zool 47:513-528

Mukai Y, Baba N, Ishii M (2005) The water system of traditional rice paddies as an important habitat of the giant water bug, Lethocerus deyrollei (Heteroptera: belostomatidae). J Insect Cons 9:121-129

Mukai Y, Suzuki T, Makino W, Iwabuchi T, So M, Urabe J (2014) Ecological impacts of the 2011 Tohoku Earthquake Tsunami on aquatic animals in rice paddies. Limnology. doi:10.1007/s10201014-0432-5

Natuhara Y (2013) Ecosystem services by paddy fields as substitutes of natural wetlands in Japan. Ecol Eng 56:97-106

Negishi JN, Tamaoki H, Watanabe N, Nagayama S, Kume M, Kayaba Y, Kawase M (2014) Imperiled freshwater mussels in drainage channels associated with rare agricultural landscape and diverse fish communities. Limnology. doi:10.1007/s10201-014-0430-7

Verdonschot CM, Verdonschot FM (2014) Shading effects of freefloating plants on drainage-ditch invertebrates. Limnology. doi:10.1007/s10201-013-0416-x

Wezel A, Oertli B, Rosset V, Arthaud F, Leroy B, Smith R, Angélibert S, Bornette G, Vallod D, Robin J (2014) Biodiversity patterns of nutrient-rich fish ponds and implications for conservation. Limnology. doi:10.1007/s10201-013-0419-7 